\title{
Situational Leadership as View by Nurses in Government and Private Hospitals
}

\author{
Diwa Agus Sudrajat, Fikri Zulfikar, Linlin Lindayani*. \\ Sekolah Tinggi Ilmu Keperawatan Jawa Barat, Indonesia \\ Corresponding author: linlinlindayani@gmail.com
}

\begin{abstract}
Background: Leadership as an indicator of the quality of human resources is a very determining factor in the success of an organization such as a hospital. Leadership style depends also on the maturity of individuals or groups as followers.

Purpose: This study aimed to explore situational leadership of head nurse as viewed by nurses in government and private hospitals.

Methods: this study uses descriptive research method with cross-sectional approach. The time of the study will begin in May 2019 until June 2019. The instrument used in this study was the leadership style questionnaire model of Harsey and Blanchard.

Results: The leadership style of head nurse in the majority government hospitals is delegate $(38.5 \%)$ and followed by the leadership style of consultation (38.5\%), participation (18.5\%) and at least instruction (13.8\%). The leadership style of head nurses in private hospitals is also almost the same as government hospitals where the majority of implementing nurses rate the room head in the delegate style (48\%), which is followed by the leadership style of consultation (23\%), participation (20\%) and most the least is the leadership style of instruction (9\%).
\end{abstract}

Conclusion: The leadership style of head nurse both government and private hospitals iwas dominated by delegation and consultation.

Keywords: Leadership, Nurse, Hospital. 


\section{Journal Of Nursing Practice}

http://thejnp.org

ISSN: 2614-3488 (print); 2614-3496 (online)

Vol.3 No.2. April 2020. Page.286-290

\section{BACKGROUND}

Leadership as an indicator of the quality of human resources is a determining factor in the success of an organization such as a hospital (Siagian; 2006). Gillies (1996) states that leadership styles can be identified based on the behavior of the leader himself. A person's behavior is influenced by years of experience in his life. Therefore, one's personality will be the leadership style used. A person's leadership style tends to be very varied and different. There are many different types of leadership styles developed by many experts, one of which is the situational leadership style developed by Harsey \& Blanchard that the right leadership style depends also on the readiness / maturity of individuals or groups as followers (Paul Hersey and Ken Blanchard 1998).

Situational leadership theory (Situational Leadership Theory-SLT) developed based on the thought that there is no effective leadership style for all situations. The strength that is in the leader and owned by the group (interpersonal relationship between the two) and the environment (task orientation) will also determine a person's leadership style if he relates to his staff (Munijaya; 2004). According to the research conducted by Darmawan Insan Personal and (Insan \& Yuniawan, 2016) the influence of participative leadership style, compensation work environment and organizational culture on employee performance that the results of the study proved that participative leadership style did not significantly influence employee performance, this can be seen from the value $t$ for participative leadership style is 0.281 with a significance result of $0.780>0.05$. The results of this study support the research of Mamesah and Kusumaningtyas (2009) which states that the participative leadership style has no effect on employee performance. So that the weaknesses of this study can be seen is only examining one type of leadership style while in situational leadership theory harsey and blanchard there are 4 leadership styles.

\section{OBJECTIVE}

This study aimed to explore situational leadership of head nurse as viewed by nurses in government hospitals and private hospitals.

\section{METHODS}

This type of research conducted in this study uses descriptive research method with cross-sectional approach. The researchers conducted research at Dustira Hospital and Hermina Arcamanik Hospital and were conducted in the inpatient room. The time of the study will begin in May 2019 until June 2019.

The population in this study is the head of the room in government hospitals and private hospitals. The inclusion criteria were nurses who were active in the Dustira Hospital and Arcamanic Hermina Hospital. Samples were taken using convenience sampling technique. Estimated sample size was calculated using G-Power software Version 3.0.10 for comparison between the two $F$ test groups with the assumption $\alpha=$ 0.05 , medium effect size $=0.15$, power level $=0.95,2$ repeated measurements. With an estimated minimum sample size of 129 people. In this study researchers only got 100 respondents from both hospitals.

The instrument used in this study was the leadership style questionnaire model of Harsey and Blanchard. Where there are 20 questions consisting of 4 styles: instructional leadership style, consultation leadership style, delegation leadership style, and participation leadership style. Where in this questionnaire was tested the validity with the results of $r$ table 0.361 . 


\section{Journal Of Nursing Practice}

http://thejnp.org

ISSN: 2614-3488 (print); 2614-3496 (online)

Vol.3 No.2. April 2020. Page.286-290

Data analysis that will be conducted in this research is univariate data analysis which aims to explain and describe the characteristics of variables. Univariate analysis uses frequency distribution analysis.

\section{RESULTS}

From table 1 it can be seen that the most dominant leadership style used by the head of the room in private and government hospitals is the leadership style of participation and participation with a percentage of $38.5 \%$ each, then the leadership style which next is the instruction style with percentage $18,5 \%$ and finally the leadership style of participation.

Table 1 distribution of leadership styles in government hospitals.

\begin{tabular}{lll}
\hline Leadership Style & $\mathrm{n}$ & Percetage \\
\hline Instructions & 12 & $18.5 \%$ \\
Consultation & 22 & $38.5 \%$ \\
Delegation & 22 & $38.5 \%$ \\
Participation & 9 & $13.8 \%$ \\
Total & 65 & $100 \%$ \\
\hline
\end{tabular}

The results obtained in private hospitals are also almost similar to the percentage of leadership styles in government hospitals where the dominant leadership style is delegate style with a percentage of $48 \%$, the second leadership style is consultation leadership style with $22.9 \%$ percentage, next is leadership style instruction with a percentage of $20 \%$ and the least is the participation leadership style with an amount of $8.6 \%$ (Table 2).

Table 2 distribution of leadership styles in private hospitals.

\begin{tabular}{lcc}
\hline \multicolumn{1}{c}{ Leadership Style } & $\mathrm{n}$ & Percetage \\
\hline Instructions & 7 & $20 \%$ \\
Consultation & 8 & $22.9 \%$ \\
Delegation & 17 & $48.6 \%$ \\
Participation & 3 & $8.6 \%$ \\
Total & 35 & $100 \%$ \\
\hline
\end{tabular}

\section{DISCUSSION}

From the results of the study showed that most respondents rated the leadership style of the head nursesin a private hospital with a government hospital as the leadership style of the delegation (S3 style) as many as $38.5 \%$ of respondents. This leadership style has the characteristics of low directing behavior and high supportive behavior. Leaders and subordinates give ideas to each other and together make decisions and evaluate the implementation of tasks as well as leaders encourage subordinates to complete tasks.

This delegation style is suitable to be applied and is needed for the level of development of capable or hesitant subordinates or executors. The level of ability of subordinates "moderate" to "high" but has an uncertain commitment. Cristina Catur Widianti mentioned in her journal that the style of delegative leadership influences the performance of the employees of PT Bank Mandiri Jakarta City KCP, this means that if the leadership style increases, the employee's performance will also increase. Therefore, with the results obtained in government hospitals with the most number of nurses choosing a delegative leadership style, it is suitable to be applied to increase nurse skills and can improve employee performance as explained by Kristina chess widianti. 
The leadership style of head nurse that is rated by the next most respondents is the leadership style of consultation (S2 style) as many as $38.5 \%$ of respondents with the characteristics of directing high behavior and high support. In this style the leader explains the decisions taken, accepts the opinions of subordinates by conducting two-way communication and directing and continuously supervising the completion of the task. This style is needed in implementing nurses who have low to moderate abilities and low commitment. In his journal Toto Raharjo also said that the directive style influences employee performance and has the highest variable in relation to performance improvement.

It can be seen that the most results in government hospitals are the delegative and participative leadership style, this is possible because both the delegative and participatory styles can influence employee performance. Furthermore, an assessment of $18.5 \%$ of respondents stated that the head of the room in the government and private hospitals had a participation leadership style (S4 style). The characteristics of this leadership style are low directing and supportive behavior. This style is good for staff who have high ability and commitment. According to Yudi Atmaja this leadership style was deemed inappropriate. If it turns out the implementing nurse still needs guidance or control from the head of the room, this style will even have a negative impact on the performance of the implementing nurse and the purpose of the room that is the responsibility of the room head. From this it can be seen that in reality the responsibility cannot be delegated. Conversely, if the head of the room delegates authority to a capable nurse, the head of the room will no longer be burdened by routine tasks and the nurse will also develop confidence and responsibility for the tasks given.

The leadership style of head nurses in government hospitals with private hospitals rated by at least respondents, as many as $13.8 \%$ of respondents were instructional leadership styles (S1 style) where this style had the characteristics of high directing behavior and low supportive behavior. Leaders in this style provide specific instructions about the role and goals of the leader, explaining what, how, when and where work must be done by subordinates through one-way communication so that the role of subordinates is very minimal and leaders conduct strict supervision and solve problems and make their own decisions. This style is needed for subordinates who have low ability and high commitment. This leadership style is not appropriate to be applied in a hospital room because it does not encourage and involve implementing nurses in thinking of new ideas and ideas in carrying out tasks

According to the journalist, Audra Febriandini Nugroho, that to create effective leadership, there are three ways, namely (1) modeling, which means that the example of the principal is modeled or modeled by the teacher in the school he dreams of (2) monitoring means monitoring the performance of the teacher to the classroom when the teacher carries out the learning process in the classroom and utilizes the results of the monitoring for further coaching (3) professional dialogue and discussion means that it means actively discussing the effective aspirational of democratic and scientific productive inspiration about performance results and follow-up plans to improve the quality of the process and student learning outcomes.

From the two data above, the researcher analyzes that in order for the leadership style of this instruction to be applied appropriately, a modeling monitoring and professional dialogue discussion must be carried out so that the implementing nurse still feels involved in decision making and problem solving. 


\section{Journal Of Nursing Practice}

http://thejnp.org

ISSN: 2614-3488 (print); 2614-3496 (online)

Vol.3 No.2. April 2020. Page.286-290

\section{CONCLUSION}

The leadership style of head nurse in the majority government hospitals is delegate $(38.5 \%)$ and followed by the leadership style of consultation (38.5\%), participation $(18.5 \%)$ and at least instruction $(13.8 \%)$. The leadership style of head nurses in private hospitals is also almost the same as government hospitals where the majority of implementing nurses rate the room head in the delegate style $(48 \%)$, which is followed by the leadership style of consultation (23\%), participation $(20 \%)$ and most the least is the leadership style of instruction (9\%). With the results of the dominant leadership style among the delegates, consultations, and participation styles this is appropriate. To carry out the leadership style of instruction, modeling should be done, which means that the example of the principal is modeled or modeled by the teacher in the school whose dreams are monitored, means monitoring the performance of the teacher to the class while the teacher is carrying out the learning process in the classroom and utilizing the results of the monitoring for more coaching continued professional dialogue and discussion.

\section{REFERENCES}

Blancard, H. a. (1993). Manajemen of Organisation Behaviour: Utilizing Human Resources. New Jersey: Prentice-Hall International, Inc.

Blanchard, K. (1985). LBA II, Leader Behavior Analysis II, Self Perpection of Leadership Style. Blanchard Training and Development.

Blanchard, K. (2007). Leading At A Higer Level. Alih bahasa. Jakarta: Media Komputindo.

C.J., H. (1998). Magement Decision Making for Nurses. Edisi 3 . Philadelphia: Lippincott. Gibson. (1996). Organisasi, Perilaku, Struktur, Proses. Jakarta: Binarupa Aksara.

I., D. K. (2010). Rencana Pembangunan Kesehatan Menuju Indonesia Sehat. Jakarta: Departemen Kesehata R. I.

Munijaya. (2004). Manajemen Kesehatan. jakarta: EGC.

Notoatmojo. (2010). Metodologi Penelitian Kesehatan. Rineka Cipta.

Nursalam. (2007). Manajaemen Keperawatan : Aplikasi Dalam Peraktik Keperawatan Propesional. Jakarta: Salemba Medika.

Nursalam. (2012). Manajemen Keperawatan : Aplikasi Dalam Praktik Keperawatan ProfesionalEdisi Ketiga. Jakarta: Salemba Medika.

Nursalam. (2015). Manajemen Keperawatan. Jakarta Selatan: Salemba Medika.

R.I., D. K. (2010). Rencana Pembangunan Kesehatan Menuju Indonesia Sehat . Jakarta: Depertemen Kesehatan R.I.

Sharfina. (2014). Kepemimpinan Kepala Ruangan. 1-5.

Siagian. (2006). Teori dan Praktek Kepemimpinan. Jakarta: Rineka Cipta.

Syah, D. Z. (2015). Gambaran Gaya Kepemimpinan Kepala Ruangan di Rumah Sakit Pku Muhammadiyah Yogyakarta. Media Ilmu Kesehatan, 210-219.

Syaiful Anwar, \& Widyaiswara Utama. (2014). Analisis kebijakan Publik. 5.

Tampi, B. J. (2014). Pengaruh Gaya Kepemimpinan dan Motivasi Terhadap Kinerja Karyawan Pada PT. Bank Negara Indonesia.

Yudiaatmaja, F. (2013). Leadership. 29-38. 